\title{
AKUNTANSI FORENSIK DAN AUDIT INVESTIGATIF DALAM PENGUNGKAPAN FRAUD
}

\section{FORENSIC ACCOUNTING AND INVESTIGATIVE AUDITS IN DISCLOSURE OF FRAUDS}

\author{
Dewi Anggraini ${ }^{1}$, Eri Triharyati ${ }^{2}$, Helen Anggia Novita ${ }^{3}$ \\ Universitas Bina Insan Lubuklinggau ${ }^{1,2,3}$ \\ dewi2019@gmail.com ${ }^{1}$
}

Submit, 25-05-2019 Accepted, 23-06-2019 Publish, 29-06-2019

\begin{abstract}
ABSTRAK
Akuntan forensik bertugas memberikan pendapat hukum dalam pengadilan (litigation). Disamping itu, ada juga peran akuntan forensik dalam bidang hukum diluar pengadilan (non itigation) misalnya dalam membantu merumuskan alternatif penyelesaian perkara dalam sengketa, perumusan perhitungan ganti rugi dan upaya menghitung dampak pemutusan / pelanggaran kontrak. Audit investigative, Suatu bentuk audit atau pemeriksaan yang bertujuan untuk mengidentifikasi dan mengungkap kecurangan atau kejahatan dengan menggunakan pendekatan, prosedur dan teknikteknik yang umumnya digunakan dalam suatu penyelidikan atau penyidikan dalam suatu kejahatan. Karena tujuan audit investigasi adalah untuk mengidentifikasi dan mengungkap kecurangan atau kejahatan, maka pendekatan, prosedur dan teknik yang digunakan di dalam audit investigatif relatif berbeda dengan pendekatan, prosedur dan teknik yang digunakan di dalam audit keuangan, audit kinerja atau audit dengan tujuan tertentu lainnya. Dalam audit investigatif, seorang auditor memulai suatu audit dengan praduga/ indikasi akan adanya kemungkinan kecurangan dan kejahatan yang akan diidentifikasi dan diungkap melalui audit yang akan dilaksanakan. Kondisi tersebut, misalnya, akan mempengaruhi siapa yang akan diwawancarai terlebih dahulu atau dokumen apa yang harus dikumpulkan terlebih dahulu. Selain itu, dalam audit investigatif, jika memiliki kewenangan, auditor dapat menggunakan prosedur dan teknik yang umumnya digunakan dalam proses penyelidikan dan penyidikan kejahatan, seperti pengintaian dan penggeledahan. Fraud adalah proses pembuatan, beradaptasi, meniru atau benda, statistik, atau dokumen-dokumen, dengan maksud untuk menipu. Tetapi fraud bisa kita cegah dan bisa kita hindari fraud sangat merugikan berbagai pihak karena dapat menghancurkan pemerintahan maupun bisnis. Fraud berupa korupsi lebih luas daya penghancurnya.Pada dasarnya cakupan akuntansi forensik adalah fraud dalam arti yang luas.
\end{abstract}

Kata Kunci : Akuntansi Forensik, Audit Investigatif dan Fraud

\section{ABSTRACT}

Forensic accountants are tasked with providing legal opinions in litigation. Besides that, there is also the role of forensic accountants in the field of law outside the court (non-itigation) for example in helping to formulate alternative settlement cases in disputes, formulation of compensation calculations and efforts to calculate the impact of termination / breach of contract. Investative audit, a form of audit or examination that aims to identify and uncover fraud or crime by using approaches, procedures and techniques commonly used in an investigation or investigation into a crime. Because the purpose of an investigative audit is to identify and disclose fraud or crime, the approaches, procedures and techniques used in investigative audits are relatively different from the approaches, procedures and techniques used in financial audits, performance audits or audits with 
other specific objectives. In an investigative audit, an auditor initiates an audit with presumptions / indications of possible fraud and crimes that will be identified and revealed through the audit to be carried out. Such conditions, for example, will affect who will be interviewed in advance or what documents must be collected first. In addition, in an investigative audit, if it has authority, the auditor can use procedures and techniques commonly used in the investigation and investigation of crimes, such as surveillance and searches. Fraud is the process of making, adapting, imitating or objects, statistics, or documents, with the intent to cheat. But we can prevent fraud and we can avoid fraud is very detrimental to various parties because it can destroy government and business. Fraud is in the form of corruption in its wider destructive power. Basically the scope of forensic accounting is fraud in the broadest sense.

Keywords: Forensic Accounting, Investigative Audit and Fraud

\section{PENDAHULUAN}

Seiring perkembangan dunia usaha yang semakin kompleks, berkembang pula praktik kejahatan dalam bentuk kecurangan (fraud) ekonomi. Jenis fraud yang terjadi pada berbagai negara bisa berbeda, karena dalam hal ini praktik fraud antara lain dipengaruhi kondisi hukum di negara yang bersangkutan. Pada negara negara maju dengan kehidupan ekonomi yang stabil, praktik fraud cenderung memiliki modus yang sedikit dilakukan. Adapun pada negara-negara berkembang seperti Indonesia, praktik fraud cenderung memiliki modus banyak untuk dilakukan. Fraud dapat terjadi pada sektor swasta maupun sektor publik. Pada sektor swasta, banyak terdapat penyimpangan dan kesalahan yang dilakukan seseorang dalam menafsirkan catatan keuangan. Hal itu menyebabkan banyaknya kerugian yang besar bukan hanya bagi orang-orang yang bekerja pada perusahaan, akan tetapi pada investor-investor yang menanamkan dananya pada perusahaan tersebut. Seperti pada kasus (Bantuan Likuiditas Bank Indoneisa) BLBI, Bank Bali, dan Bank Century juga telah mengurangi kepercayaan investor luar negeri.

Pada tahun 2008-2009, korupsi sudah bukan merupakan rahasia publik. Banyak televisi-televisi secara terangterangan meliput dan menyiarkan adanya penangkapan para koruptor oleh KPK (Komisi Pemberantasan Korupsi). Korupsi itu sendiri kini telah dianggap sebagai penyebab akar masalah nasional, seperti biaya ekonomi tinggi, pertumbuhan ekonomi yang tidak lancar, dan penghalang investasi. Adanya lembaga pemerintahan seperti BPK (Badan Pemeriksa Keuangan), BPKP (Badan Pengawas Keuangan dan Pembangunan), Inspektorat, KPK (Komisi Pemberantas Korupsi), kalangan LSM (Lembaga Swadaya Masyarakat) dan ICW (Indonesian Corruption Watch), bahkan dibuatnya UU Nomor 31 tahun 1999 tentang Pemberantasan Tindak Pidana Korupsi jo UU Nomor 20 tahun 2001 tentang Pemberantasan Tindak Pidana Korupsi belum berhasil menuntaskan masalah korupsi yang merajalela.

Namun pada segi akuntansi, masih jarang terlihat kontribusi nyata dari akuntan dalam melawan fraud. Dalam hal ini akuntan-akuntan dituntut untuk memiliki kemampuan yang lebih dalam bidang akuntansi yang didukung oleh pengetahuan luas di bidang ekonomi, keuangan, perbankan, perpajakan, bisnis, teknologi informasi, dan tentunya pengetahuan dibidang hukum. Akuntan forensik memiliki peran yang efektif dalam menyelidiki tindak kejahatan. Akuntansi forensik merupakan penerapan 
disiplin akuntansi dalam arti luas, termasuk auditing pada masalah hukum untuk penyelesaian hukum di dalam atau di luar pengadilan (Tuanakotta, 2009). Akuntansi forensik dahulu digunakan untuk pembagian warisan atau mengungkap kasus pembunuhan. Hal ini yang menjadi dasar pemakaian istilah akuntansi dan bukan audit. Secara tegas yang membedakan antara keduanya, misalnya dalam tindak pidana korupsi menghitung besarnya kerugian keuangan negara masuk ke wilayah akuntansi.

\section{METODE PENELITIAN}

Penelitian ini dilakukan pada Laporan Media dan Catatan Sipil selama 6 (enam) bulan terhitung dari bulan Januari 2018 sampai dengan bulan Juni 2018. Penelitian ini dilakukan dengan metode analisa dengan akuntansi forensik dan audit investigative, metode penelitian yang digunakan adalah metode kualitatif, dengan data yang digunakan adalah data sekunder, dalam hal ini analisa yang digunakan yaitu secara komperatif. Dalam menganalisa Teknik pengumpulan data yang digunakan menggunakan dokumen semua yang berkaitan mengenai fraud. Penelitian ini dengan data yang diambil di media online untuk menganalisa pengungkapan fraud dengan menggunakan penerapan akuntansi forensik dan audit investigatif.

\section{HASIL DAN PEMBAHASAN}

\section{Akutansi Forensik}

Menurut Harvarindo

(2012)

akuntansi forensik adalah praktik khusus bidang akuntansi yang menggambarkan keterlibatan yang dihasilkan dari perselisihan aktual atau yang diantisipasi atau litigasi. "Forensik" berarti "yang cocok untuk digunakan dalam pengadilan hukum", dan itu adalah untuk yang standar dan potensi hasil yang umumnya akuntan forensik harus bekerja. Akuntan forensik, juga disebut sebagai auditor forensik atau auditor investigasi, seringkali harus memberikan bukti ahli pada sidang akhirnya.

Bolgna dan Lindquist (1987) mendefinisikan akuntansi forensik sebagai aplikasi dari keterampilan finansial dan investigatif mentalitas untuk memecahkan permasalahan dari isu-isu, sesuai dengan konteks aturan dalam suatu upaya pembuktian. Sedangkan, menurut Kumalahadi (2009) akuntansi forensik merupakan perpaduan antaraaccounting, auditing, dan kemampuan investigasi yang menghasilkan kekhususan yang disebutforensik accounting. Keunikan dari akuntansi forensik ini sendiri adalah metode ini memiliki kerangka berpikir yang berbeda dari audit laporan keuangan. Audit laporan keuangan lebih berprosedur dan kurang efektif dalam mendeteksi kecurangan sedangkan akuntansi forensik lebih efektif digunakan dalam mendeteksi kecurangan karena dari prosesnya metode ini terkadang lebih mengandalkan intuisi dan deduktif.

Pengamatan menunjukkan bahwa akuntansi forensic bahwa menganalisa permasalahan dalam sisi akuntansi, sehingga dianalisa dengan ilmu akuntansi yang detail, sistematis dan periodic maka suatu kasus atau masalah akan dinalisa dengan perhitungan yang tepat seperti dalam suatu kasus, yaitu kasus e-ktp yang dianlisa, dengan akuntan forensik bertugas memberikan pendapat hukum dalam pengadilan (litigation). Disamping itu, ada juga peran akuntan forensik dalam bidang hukum diluar pengadilan (non itigation) misalnya dalam membantu merumuskan alternatif penyelesaian perkara dalam sengketa, perumusan 
perhitungan ganti rugi dan upaya menghitung dampak pemutusan / pelanggaran kontrak.

\section{Audit Investigatif}

Menurut Herlambang (2011) audit investigasi yaitu suatu bentuk audit atau pemeriksaan yang bertujuan untu mengidentifikasi dan mengungkap kecurangan atau kejahatan dengan menggunakan pendekatan, prosedur atau teknik-teknik yang umumnya digunakan dalam suatu penyelidikan atau penyidikan terhadap suatu kejahatan. Suatu bentuk audit atau pemeriksaan yang bertujuan untuk mengidentifikasi dan mengungkap kecurangan atau kejahatan dengan menggunakan pendekatan, prosedur dan teknik-teknik yang umumnya digunakan dalam suatu penyelidikan atau penyidikan terhadap suatu kejahatan. Karena tujuan audit investigasi adalah untuk mengidentifikasi dan mengungkap kecurangan atau kejahatan, maka pendekatan, prosedur dan teknik yang digunakan di dalam audit investigatif relatif berbeda dengan pendekatan, prosedur dan teknik yang digunakan di dalam audit keuangan, audit kinerja atau audit dengan tujuan tertentu lainnya. Dalam audit investigatif, seorang auditor memulai suatu audit dengan praduga/ indikasi akan adanya kemungkinan kecurangan dan kejahatan yang akan diidentifikasi dan diungkap melalui audit yang akan dilaksanakan. Kondisi tersebut, misalnya, akan mempengaruhi siapa yang akan diwawancarai terlebih dahulu atau dokumen apa yang harus dikumpulkan terlebih dahulu. Selain itu, dalam audit investigatif, jika memiliki kewenangan, auditor dapat menggunakan prosedur dan teknik yang umumnya digunakan dalam proses penyelidikan dan penyidikan kejahatan, seperti pengintaian dan penggeledahan.

\section{Pengungkapan Fraud}

Fraud atau yang sering dikenal dengan istilah kecurangan merupakan hal yang sekarang banyak dibicarakan di Indonesia. Pengertian fraud itu sendiri merupakan penipuan yang sengaja dilakukan, yang menimbulkan kerugian pihak lain dan memberikan keuntungan bagi pelaku kecurangan dan atau kelompoknya, Sementara Albrecht mendefinisikan fraud sebagai representasi tentang fakta material yang palsu dan sengaja atau ceroboh sehingga diyakini dan ditindaklanjuti oleh korban dan kerusakan korban. Dalam bahasa aslinya fraud meliputi berbagai tindakan melawan hukum. Dalam akuntansi, dikenal dua jenis kesalahan yaitu kekeliruan (error) dan kecurangan (fraud). Perbedaan antara kedua jenis kesalahan ini hanya dibedakan oleh jurang yang sangat tipis, yaitu ada atau tidaknya unsur kesengajaan. Standarpun mengenali bahwa sering kali mendeteksi kecurangan lebih sulit dibandingkan dengan kekeliruan karena pihak manajemen atau karyawan akan berusaha menyembunyikan kecurangan itu. "Fraud adalah tindakan curang, yang dilakukan sedemikian rupa, sehingga menguntungkan diri sendiri / kelompok atau merugikan pihak lain (perorangan, perusahaan atau institusi)."

Kecurangan bisa terjadi di dalam sebuah profesi, contohnya profesi akuntansi. Seorang akuntan yang melakukan kecurangan dalam prosedur akuntansi akan mengakibatkan informasi akuntansi yang dihasilkan tidak akan berguna bagi pihak-pihak yang membutuhkannya. Karena sebuah informasi akuntansi yang dihasilkan dari proses akuntansi dari suatu entiti sangatlah penting, dimana informasi ini menjadi pertimbangan terhadap program 
atau kebijakan entiti tersebut untuk mencapai tujuannya. Contohnya kecurangan dalam pelaporan keuangan, kesalahan pencatatan akuntansi dapat menyebabkan salah saji material pada pelaporan keuangan.

Salah saji material pada pelaporan keuangan mengacu pada pengertian bahwa keputusan pengguna laporan keuangan akan terpengaruh/terkecoh oleh ketidakakuratan informasi yang terjadi karena salah saji tersebut. Secara umum salah saji material dapat dikategorikan menjadi dua, yaitu kualitatif dan kuantitatif. Contoh salah saji yang kategori pertama adalah kesalahan pengelompokan rekening di pelaporan keuangan. Semisal pinjaman dari bank yang berumur kurang dari 1 tahun (current) dilaporkan di rekening pinjaman jangka panjang (non-current). Efek dari kesalahan ini bisa berakibat pada tidak akuratnya perhitungan rasio lancar (current ratio) dan perbandingan hutang pada modal (debt to equity ratio). Selain itu kecurangan dalam laporan keuangan dapat menyangkut tindakan seperti manipulasi, pemalsuan atau perubahan catatan akuntansi atau dokumen pendukungnya yang menjadi sumber data bagi penyajian laporan keuangan, representasi yang salah dalam atau penghilangan dari laporan keuangan peristiwa, transaksi, atau informasi signifikan

\section{Akutansi Forensik}

Akuntan forensik bertugas memberikan pendapat hukum dalam pengadilan (litigation). Disamping itu, ada juga peran akuntan forensik dalam bidang hukum diluar pengadilan (non itigation) misalnya dalam membantu merumuskan alternatif penyelesaian perkara dalam sengketa, perumusan perhitungan ganti rugi dan upaya menghitung dampak pemutusan / pelanggaran kontrak.

Akuntansi forensik dibagi ke dalam dua bagian: jasa penyelidikan (investigative services) dan jasa litigasi (litigation services). Jasa Penyelidikan mengarahkan pemeriksa penipuan atau auditor penipuan, yang mana mereka menguasai pengetahuan tentang akuntansi mendeteksi, mencegah, dan mengendalikan penipuan, dan misinterpretasi. Jasa litigasi merepresentasikan kesaksian dari seorang pemeriksa penipuan dan jasa-jasa akuntansi forensik yang ditawarkan untuk memecahkan isu-isu valuasi, seperti yang dialami dalam kasus perceraian. Sehingga, tim audit harus menjalani pelatihan dan diberitahu tentang pentingnya prosedur akuntansi forensik di dalam praktek audit dan kebutuhan akan adanya spesialis forensik untuk membantu memecahkan masalah

\section{Audit Investigatif}

Suatu bentuk audit atau pemeriksaan yang bertujuan untuk mengidentifikasi dan mengungkap kecurangan atau kejahatan dengan menggunakan pendekatan, prosedur dan teknik-teknik yang umumnya digunakan dalam suatu penyelidikan atau penyidikan terhadap suatu kejahatan. Karena tujuan audit investigasi adalah untuk mengidentifikasi dan mengungkap kecurangan atau kejahatan, maka pendekatan, prosedur dan teknik yang digunakan di dalam audit investigatif relatif berbeda dengan pendekatan, prosedur dan teknik yang digunakan di dalam audit keuangan, audit kinerja atau audit dengan tujuan tertentu lainnya. Dalam audit investigatif, seorang auditor memulai suatu audit dengan praduga/ indikasi akan adanya kemungkinan 
kecurangan dan kejahatan yang akan diidentifikasi dan diungkap melalui audit yang akan dilaksanakan. Kondisi tersebut, misalnya, akan mempengaruhi siapa yang akan diwawancarai terlebih dahulu atau dokumen apa yang harus dikumpulkan terlebih dahulu. Selain itu, dalam audit investigatif, jika memiliki kewenangan, auditor dapat menggunakan prosedur dan teknik yang umumnya digunakan dalam proses penyelidikan dan penyidikan kejahatan seperti pengintaian dan penggeledahan.

Audit investigatif terhadap indikasi korupsi bisa dilaksanakan oleh auditor di lembaga negara dan lembaga pemerintah serta auditor di lembaga nonpemerintah. Pelaksanaan audit investigatif di lembaga negara dan lembaga pemerintah terikat kepada ketentuan yang terdapat di dalam Standar Pemeriksaan Keuangan Negara atau SPKN. Sementara itu, pelaksanaan audit investigatif oleh auditor di lembaga non-pemerintah dapat mengacu kepada standar pemeriksaan yang dikeluarkan oleh lembaga yang memiliki otoritas untuk mengeluarkan standar seperti itu, di Indonesia misalnya Institut Akuntan Publik Indonesia atau standar pemeriksaan yang lain tergantung kepada keterikatan antara auditor dengan pemberi mandat audit.

Kualifikasi Auditor Audit investigatif seharusnya dilaksanakan oleh orang-orang yang mempunyai pengalaman dan keahlian dalam melaksanakan audit investigatif. Auditor yang belum memiliki pengalaman dan keahlian harus mendapat bimbingan dari auditor lain yang memiliki pengalaman dan keahlian audit investigatif. Auditor investigatif juga perlu mempunyai pemahaman yang cukup tentang hal-hal yang akan diaudit terutama menyangkut peraturan yang berlaku serta proses bisnis yang berkaitan dengan hal-hal yang akan diaudit. Secara khusus, auditor yang akan melaksanakan audit investigatif juga harus mempunyai pemahaman yang cukup tentang ketentuan-ketentuan hukum yang berkaitan dengan hal-hal yang akan diaudit maupun ketentuanketentuan hukum yang berkaitan dengan pengungkapan kejahatan misalnya Kitab Undang-Undang Hukum Acara Pidana atau KUHAP.

\section{Fraud}

Tekanan (Unshareable pressurel incentive). Merupakan motivasi seseorang untuk melakukan fraud. Motivasi melakukan fraud, antara lain motivasi ekonomi, alasan emosional (iri/cemburu, balas dendam, kekuasaan, gengsi), nilai (values) dan apa pula karena dorongan keserakahan. Menurut SAS no. 99, terdapat empat jenis kondisi yang umum terjadi pada pressure yang dapat mengakibatkan kecurangan. Kondisi tersebut adalah financial stability, external pressure, personal financial need, dan financial targets.

Adanya kesempatan / peluang (Perceived Opportunity). Yaitu kondisi atau situasi yang memungkinkan seseorang melakukan atau menutupi tindakan tidak jujur. Biasanya hal ini dapat terjadi karena adanya internal control perusahaan yang lemah kurangnya pengawasan, dan/atau penyalahgunaan wewenang. Di antara 3 elemen fraud triangle, opportunity merupakan elemen yang paling memungkinkan untuk diminimalisir melalui penerapan proses, prosedur, dan control dan upaya deteksi dini terhadap fraud.

Rasionalisasi (Rationalization). Merupakan elemen penting dalam terjadinya fraud, dimana pelaku mencari pembenaran sebelum melakukan kejahatan, bukan sesudah melakukan 
tindakan tersebut. Rasionalisasi diperlukan agar si pelaku dapat mencerna perilakunya yang illegal untuk tetap mempertahankan jati dirinya sebagai orang yang dipercaya, tetapi setelah kejahatan dilakukan, rasionalisasi ini ditinggalkan karena sudah tidak dibutuhkan lagi. Rasionalisai atau sikap (attitude), yang paling banyak digunakan adalah hanya meminjam (borrowing) asset yang dicuri dan alasan bahwa tindakannya untuk membahagiakan orang-orang yang dicintainya.

Teknik Untuk Mendeteksi

Kecurangan Laporan Keuangan management and Directors Manajemen hampir selalu terlibat ketika kecurangan terhadap laporan keuangan yang terjadi. Seperti penggelapan dan penyimpangan, kecurangan laporan keuangan biasanya dilakukan oleh individu tertinggi dalam organisasi, dan paling sering atas nama organisasi. Karena manajemen biasanya terlibat, manajemen dan direksi harus diselidiki untuk menentukan paparan dan motivasi mereka saat melakukan penipuan. Dalam mendeteksi kecurangan laporan keuangan, diperoleh pemahaman manajemen dan apa yang memotivasi mereka adalah setidaknya sama pentingnya dengan memahami laporan keuangan.

Relationship with Others

Financial statement fraud sering dilakukan dengan membantu organisasi nyata atau fiktif lainnya. Hubungan yang harus dideteksi adalah sebagai berikut: Hubungan dengan lembaga keuangan, Hubungan dengan pihak organisasi dan individu, Hubungan dengan auditor eksternal, Hubungan dengan pengacara, Hubungan dengan investor, Hubungan dengan lembaga peraturan (regulator). Organization and Industry Financial statement fraud seringkali tidak terdeteksi dengan menciptakan struktur organisasi yang memudahkan untuk menyembunyikan fraud. Atribut organisasi yang menyarankan eksposur potensi penipuan mencakup hal-hal seperti terlalu kompleks struktur organisasi, organisasi tanpa sebuah departemen audit internal. Peneliti harus memahami siapa pemilik dari sebuah organisasi.

Financial Result and Operating Characteristics Banyak yang dapat dipelajari tentang kecurangan laporan keuangan yang dengan erat memeriksa pengelolaan dan dewan direksi, hubungan dengan orang lain, dan sifat organisasi. Melihat ketiga elemen biasanya melibatkan prosedur 22 yang sama untuk semua jenis penipuan laporan keuangan, apakah rekening tersebut dimanipulasi. Diantaranya adalah rekening pendapatan, rekening aset, kewajiban, pengeluaran, atau ekuitas. Jenis eksposur diidentifikasi oleh laporan keuangan dan karakteristik operasi dari organisasi. Dalam memeriksa keuangan pernyataan untuk menilai eksposur kecurangan, pendekatan terhadap laporan keuangan nontradisional harus dilakukan. Gejala kecurangan yang paling sering terdeteksi adalah melalui perubahan dalam laporan keuangan.

Internal Auditor. Institute of Internal Auditing (IIA) mendefinisikan internal auditing sebagai aktivitas pemberian keyakinan serta konsultasi yang independen dan obyektif, yang dirancang untuk menambah nilai dan memperbaiki operasi organisasi. Definisi lain mengatakan internal auditing sebagai suatu penilaian yang dilakukan oleh pegawai perusahaan yang terlatih terhadap ketelitian dan efisiensi catatancatatan (akuntansi) perusahaan serta pengendalian internal yang terdapat 
dalam perusahaan. Tujuannya adalah membantu manajemen dalam pelaksanaan tanggungjawabnya dengan memberikan analisa, penilaian, saran dan komentar mengenai kegiatan yang diaudit.

External Auditor. Tidak hanya internal auditor yang diperlukan dalam mendeteksi kecurangan terhadap suatu perusahaan. External auditor juga sangat diperlukan, yang bertujuan dapat menganalisa jika internal auditor mengalami kesulitan untuk mnedeteksi kecurangan.

Berdasarkan uraian diatas, dapat diketahui kecurangan (fraud) ialah sebuah istilah umum, dan mencakup semua sarana dengan berbagai kecerdikan yang dapat dirancang oleh manusia, yang terpaksa dilakukan oleh satu individu, untuk mendapatkan keuntungan lebih dari pihak lain oleh pernyataan palsu. Tidak ada aturan yang pasti dan tidak berubahubah yang dapat diletakkan sebagai proporsi umum dalam mendefinisikan penipuan, karena termasuk kejutan, tipuan, licik dan cara-cara yang tidak adil dimana pihak lain ditipu.

Hal tersebut dapat dipicu oleh beberapa faktor didalamnya diantaranya tekanan, adanya kesempatan, dan rasionalisasi. Faktor-faktor ini lah yang menjadikan kecurangan dapat merajalela di segala aspek, tidak menutup kemungkinan di dalam bidang akuntansi. Oleh karena itu sudah selayaknya tindakan kecurangan harus dicegah oleh siapapun juga. Adapun teknik-teknik untuk mendeteksi sebuah kecurangan, hal tersebut dapat membantu pihak-pihak yang mengatasi kecurangan.

\section{PENUTUP}

\section{Kesimpulan}

Audit investigative, Suatu bentuk audit atau pemeriksaan yang bertujuan untuk mengidentifikasi dan mengungkap kecurangan atau kejahatan dengan menggunakan pendekatan, prosedur dan teknik-teknik yang umumnya digunakan dalam suatu penyelidikan atau penyidikan terhadap suatu kejahatan. Karena tujuan audit investigasi adalah untuk mengidentifikasi dan mengungkap kecurangan atau kejahatan, maka pendekatan, prosedur dan teknik yang digunakan di dalam audit investigatif relatif berbeda dengan pendekatan, prosedur dan teknik yang digunakan di dalam audit keuangan, audit kinerja atau audit dengan tujuan tertentu lainnya. Dalam audit investigatif, seorang auditor memulai suatu audit dengan praduga/ indikasi akan adanya kemungkinan kecurangan dan kejahatan yang akan diidentifikasi dan diungkap melalui audit yang akan dilaksanakan. Kondisi tersebut, misalnya, akan mempengaruhi siapa yang akan diwawancarai terlebih dahulu atau dokumen apa yang harus dikumpulkan terlebih dahulu. Selain itu, dalam audit investigatif, jika memiliki kewenangan, auditor dapat menggunakan prosedur dan teknik yang umumnya digunakan dalam proses penyelidikan dan penyidikan kejahatan, seperti pengintaian dan penggeledahan.

Fraud adalah proses pembuatan, beradaptasi, meniru atau benda, statistik, atau dokumen-dokumen, dengan maksud untuk menipu. Tetapi fraud bisa kita cegah dan bisa kita hindari fraud sangat merugikan berbagai pihak karena dapat menghancurkan pemerintahan maupun bisnis. Fraud berupa korupsi lebih luas daya penghancurnya.Pada dasarnya cakupan akuntansi forensik adalah fraud dalam arti yang luas.

\section{Saran}

Dalam hal ini akuntan-akuntan dituntut untuk memiliki kemampuan yang 
lebih dalam bidang akuntansi yang didukung oleh pengetahuan luas di bidang ekonomi, keuangan, perbankan, perpajakan, bisnis, teknologi informasi, dan tentunya pengetahuan dibidang hukum. Akuntan forensik memiliki peran yang efektif dalam menyelidiki tindak kejahatan. Akuntansi forensik merupakan penerapan disiplin akuntansi dalam arti luas, termasuk auditing pada masalah hukum untuk penyelesaian hukum di dalam atau di luar pengadilan

\section{DAFTAR PUSTAKA}

Bologna, J. G., dan Lindquist, $R . \quad J$. (1987). Fraud auditing and forensic accounting. New York: Willey.

Harvarindo. (2012). Pengantar Forensik Auditing. Jakarta: CPA MBA

Herlambang. (2011). Pengertian Audit Investigasi.

MasherlaWordpresss:http://mashe rla.wordpress.com/2011/11/22/pen grtian -audit-investigasi/. Di akses tanggal 27 januari 2019

Kumalahadi. (2009). Forensic Auditing : Fraud Audit dan Forensic Accounting. Ikatan Akuntan Indonesia. Jakarta.

Tuanakotta, Theodorus. M. (2009). Menghitung KerugianKeuangan Negara dalam Tindak Pidana Korupsi. Salemba Empat: Jakarta. 